Lohmann, G. and D. G. Pearce (2012). "Tourism and transport relationships: the suppliers' perspective in gateway destinations in New Zealand." Asia Pacific Journal of Tourism Research 17(1): 14-29.

\title{
Tourism and transport relationships: the suppliers' perspective in gateway destinations in New Zealand
}

\author{
By
}

\section{Gui Lohmann and Douglas G. Pearce}

Gui Lohmann is Lecturer in Transport and Tourism, School of Tourism and Hospitality Management, Southern Cross University, Locked Mail Bag \#4, Coolangatta, QLD, Australia.

Email: gui.lohmann@scu.edu.au

Douglas Pearce is Professor of Tourism Management, Victoria Management School, Victoria University of Wellington, PO Box 600, Wellington, New Zealand.

Email: douglas.pearce@vuw.ac.nz 
Lohmann, G. and D. G. Pearce (2012). "Tourism and transport relationships: the suppliers' perspective in gateway destinations in New Zealand." Asia Pacific Journal of Tourism Research 17(1): 14-29.

\section{Tourism and transport relationships: the suppliers' perspective in gateway destinations in New Zealand}

This paper provides a supply-side perspective on how tourism development might be fostered by enhancing the links between tourism and transport. This question is explored by identifying issues raised by tourism suppliers relating to the Cook Strait ferry services between Wellington and Picton (New Zealand) and examining how visitation in these two gateways might be developed so that they have more of a destination function. Five major themes emerged: the characteristics and products of contrasting places; sales and marketing; the implications of ferry cancellations; fast ferry speed restrictions and environmental impacts; and threats and opportunities from the creation of another gateway ferry port in Clifford Bay. The question of destination development is thus extended by focusing on ferries, a less commonly studied mode of transport; drawing on the perspectives of tourism suppliers, stakeholders whose voice is rarely heard in the transport and tourism literature; and in studying places with multiple nodal functions.

Keywords: gateways, destinations, ferries, transport, tourism development, suppliers.

\section{Introduction}

Transport provision is a key element in the development of tourism. Historically, the growth of tourism has been closely associated with advances in transport technology which have progressively facilitated access between markets and destinations throughout the world as the expansion of railways was followed by the rise in car ownership and then air travel (Pearce, 1989). Changes in the way in which transport services are structured and marketed have also had a significant impact on the growth of tourism in particular places, for example the advent of air charters to the Mediterranean in the 1960s (Pearce, 1987) and more recently the emergence of low cost air carriers (Graham \& Dennis, 2010). As a result of these close connections, the role of transport in tourism development commonly appears to be taken for granted as these links are not often addressed explicitly or in detail in the literature on tourism and transport (Duval, 2007; Khadaroo \& Seetanah, 2007; Page, 1994). More commonly, attention is given to the characteristics and issues of particular travel modes, especially air transport, or the analysis of patterns of tourist travel through demand surveys of passengers. 
Lohmann, G. and D. G. Pearce (2012). "Tourism and transport relationships: the suppliers' perspective in gateway destinations in New Zealand." Asia Pacific Journal of Tourism Research 17(1): 14-29.

What is needed now is more research focusing directly on the relationships between tourism development and transport. This paper seeks to offer greater insight into these links by identifying and discussing issues raised by those directly involved in providing tourism and transport services. In particular, the paper gives voice to supply-side stakeholders with regard to the ferry services operating between two New Zealand gateways, Wellington and Picton. In analyzing and discussing their views on how these places might be developed further as destinations by capturing a greater share of transiting passengers' visitation, the paper reveals a range of dimensions to the relationship between transport and tourism development that have previously been subject to little research.

\section{Literature review}

Conceptually the links between tourism and transport have been treated in different ways and in varying degrees in the various models of tourism development. Transport is essentially ignored in the most frequently cited of these, Butler's (1980) tourist area life cycle, which focuses on the internal evolution of destinations independent of their external connections. Transport is one of four key factors (along with resorts, tourist behavior and the attitudes of decision makers) that Miossec (1977) incorporated in his five-phase model of tourism development. Transport is shown to play a key role in opening up a destination: the links between transport and an increasing number of resorts intensify, excursion circuits develop and in the last phase a situation of maximum connectivity results. Moreover, these changes are linked to those in the other three factors: as the industry expands, an increasingly complex hierarchical system of resorts and transport networks emerges, tourist awareness and behavior evolves, and changes in local attitudes may lead to complete acceptance of tourism, the adoption of planning controls or even rejection of this growing activity. Likewise, transport infrastructure is one of the key components of the Resort Development Spectrum developed by Prideaux (2000: p.233):

Growth occurs as a result of expansion of the resort's infrastructure and parallel development of new market sectors. The key components determining the shape of the growth curve are the willingness of suppliers to 
Lohmann, G. and D. G. Pearce (2012). "Tourism and transport relationships: the suppliers' perspective in gateway destinations in New Zealand." Asia Pacific Journal of Tourism Research 17(1): 14-29.

invest in new tourist facilities, the rate of construction of new or expanded transport infrastructure designed to transport additional tourists from new markets, capacity of the resort with respect to physical and ecological constraints and success in attracting new market sectors. The role of external political and economic forces will also become evident as the resort moves into the international market place.

Dredge (1999) offers a model from a spatial planning perspective that draws together various ideas and concepts regarding travel patterns, attraction systems and nodal structure in which the functions of different places are schematically outlined.

These models provide useful general frameworks to analyze tourism development but by their schematic nature they do not take account of specific destination characteristics such as location or size. This may not matter to the many tourism researchers who continue to use the term destination in a rather loose or general sense (Framke, 2002). However, an emerging body of literature is stressing the need to differentiate places in terms of the functions they may play and to be more precise about the how terms and concepts are used and applied (Lohmann \& Pearce, 2010). This is consistent with much work in transport studies where concepts such as hubs have acquired a particular technical meaning (Dennis, 1994).

Gateways in a general sense are seen as major entry/exit points into or out of a national or regional system (Pearce, 2001b). Gateways not only link other nodes within a national or regional network but also serve to link one network to another (Burghardt, 1971). According to Dredge (1999: p.786-787), 'They may be sharply focused at a particular point along a route or involve a gradual transition from one destination to another'. As Zurick (1992) observes, gateways can exist at a range of scales. Several writers have considered the gateway or portal function of communities adjacent to national parks (Ewert, 1996; Mules, 2005; Yuan \& Christensen, 1994). For others, gateway cities are synonymous with large metropolitan centers (Bowden, 2006; Caruana \& Simmons, 1995; Ley \& Murphy, 2001; Page, 2001; Short, Breitbach, 
Lohmann, G. and D. G. Pearce (2012). "Tourism and transport relationships: the suppliers' perspective in gateway destinations in New Zealand." Asia Pacific Journal of Tourism Research 17(1): 14-29.

Buckmand, \& Essex, 2000). In their study of MICE tourism, for instance, Mistilis and Dwyer (1999: p.448) define gateways simply as 'a capital city in a state or territory...; non-gateway is any other locality outside a gateway...'. Transport analysts, however, tend to give a more theoretical account of gateway functions. Fleming and Hayuth (1994) consider the role of gateways and other transportation hubs in terms of centrality and intermediacy, the latter being used (p.4) to describe 'locations between important origins and destinations'. Proximity - the attribute of being close to a market or set of productive resources - is another factor included by Fleming and Hayuth, according to whom one of the clearest examples is gateway proximity to tourist attractions.

O’Connor (1995) uses these ideas of centrality, intermediacy and proximity to examine changes in airport development in Southeast Asia.

Lohmann and Pearce (2010) elaborate on a set of these concepts - origins, destinations, gateways, hubs, and stopovers - and discuss and illustrate means of operationalizing them. Moreover, as their study and other research shows, places may have multiple functions as reflected in such terms as 'gateway hubs' (Caves \& Gosling, 1999) and 'gateway destination' (Lew \& McKercher, 2002). Various attributes are taken into account in conceptualizing and operationalizing these nodal functions but a common element is where places are located in travel networks and visitor circuits as determined by surveys of visitors' travel patterns. Lew and McKercher (2002) analyzed the itineraries of visitors to Hong Kong in terms of their origin, visit to Hong Kong and other destinations, and linkages between these. Lohmann and Pearce (2010) took into account the travel patterns of ferry passengers with respect to length of stay, purpose of visit and Trip Index (Pearce and Elliott, 1983).

Empirical research on multi-functional nodes has focused on the development of major air gateways and hubs into major destinations. In a largely descriptive account of the development of tourism in Singapore, Low and Heng (1997) outline conditions for gateways and then consider the opportunities and policy implications for further growth. Further policy implications for Singapore are considered by Chang and Ragutraman (2001: p. 62) who emphasize the importance of the city-state's regional connections: 'While past tourism policies focused on the development of local attractions, hotels and infrastructure, the new millennium with its emphasis on a "borderless world" and 
Lohmann, G. and D. G. Pearce (2012). "Tourism and transport relationships: the suppliers' perspective in gateway destinations in New Zealand." Asia Pacific Journal of Tourism Research 17(1): 14-29.

“shrinking earth" demands a "transborder approach" towards tourism development'.

Lohmann et al. (2009) show how Singapore and Dubai were able to transform themselves into global tourism destinations through the establishment of wellorchestrated strategies involving their airlines, airports, tourism suppliers and destination management organizations.

Other research has considered port gateways and ferry services, generally with little or no specific reference to the development of tourism (Baird, 1999). Murphy and Keller (1990) concluded their analysis of the travel patterns of ferry passengers to Vancouver Island with mention of opportunities for developing new travel experiences but they do not elaborate on how these might be developed and by whom. Likewise, Graham and Russell (2001) carried out a segmentation analysis of passengers on Scottish ferries. Although their recommendations suggest partnership involvement between businesses and other services used by passengers in the ferry ports this is not followed up in their study. Five key issues and challenges were identified by Muir, Jabour and Carlsen (2007) in their discussion of developing East Antarctic tourism from Hobart in Australia: access and distance; tour operator interest and infrastructure availability; governance and policy; gateway facilities and localized activities; and safety. Of these, facilities and activities within Hobart itself appeared to be less significant than questions of access and distance, a function of the geographical context.

This paper thus contributes to this literature by offering a supply-side perspective on how tourism development might be fostered by enhancing the links between tourism and transport. The paper explores this question by identifying issues raised by tourism suppliers relating to the ferry services between Wellington and Picton and how visitation in these two gateways might be developed so that they have more of a destination function. The question of destination development is thus extended by focusing on a mode of transport - ferries - that has received relatively little attention in this literature; based on interviews with tourism suppliers, stakeholders whose voices are rarely heard in this field; and in places with multiple nodal functions, a phenomenon that has only recently attracted much interest from researchers. In its supply-side approach the paper complements the study by Lohmann and Pearce (2010) which analyzed the patterns of demand of Cook Strait ferry passengers in order to identify the 
Lohmann, G. and D. G. Pearce (2012). "Tourism and transport relationships: the suppliers' perspective in gateway destinations in New Zealand." Asia Pacific Journal of Tourism Research 17(1): 14-29.

different nodal functions of Wellington and Picton, as well as strategies to lengthen stays in both centers.

\section{Context and Methodology}

Case selection is an important methodological consideration (Yin, 2003). Wellington and Picton were chosen for this study as they represent two linked but contrasting nodes that a priori would exhibit multiple functions. Located respectively at the south of the North Island and north of the South Island and connected by the inter-island ferry services (Figure 1), Wellington and Picton typify the eccentric location at the end of a catchment area characteristic of many gateways (Burghardt, 1971). Wellington's central location within the country was the main reason why the seat of government was transferred there in 1865. As the nation's capital, the city has a significant amount of business travel and in recent years has attracted a growing number of tourists through the development of a vibrant arts and café culture, the successful promotion of events, an active marketing campaign and the opening in 1998 of the National Museum of New Zealand - Te Papa Tongarewa which draws a million visitors a year (Doorne, 2000; Pearce, 2007; Pearce \& Tan, 2004). With a city population of 164000 and a regional population twice that size, Wellington also attracts a large number of visits from friends and relatives and acts as a major source of domestic tourists. In 2004, 4.5 million visitors spent 8.3 million nights in the city (Pearce, 2007). In contrast, Picton is a small town of 4,000 residents, a railhead located at the end of Queen Charlotte Sound and a popular summer destination for visitors who enjoy a range of water-based activities, walking and mountain biking. Visitors to Picton are estimated to reach a daily peak of 20000 in the height of summer. Wellington also is an important air hub with the busiest airport in New Zealand in terms of scheduled domestic flights but it ranks a distant third to Auckland and Christchurch in terms of international arrivals (Pearce, 2007). Picton has a very small airport with flights to the capital operated by 12 -seat propeller aircraft. [Include Figure 1 about here]

Given these characteristics, it is not surprising that Lohmann and Pearce's (2010) analysis of the nodal functions of Wellington and Picton showed clear differences between the two places (Table 1). The former has a more even range of functions while 
Lohmann, G. and D. G. Pearce (2012). "Tourism and transport relationships: the suppliers' perspective in gateway destinations in New Zealand." Asia Pacific Journal of Tourism Research 17(1): 14-29.

the gateway role (no overnight stay, main purpose of visit being to catch the ferry) is dominant in Picton. The passenger traffic that passes through gateways provides an opportunity to attract potential tourists to spend time in these places and purchase and use tourism services and products there. However, the results of Lohmann and Pearce's (2010) passenger survey indicated that attempts to modify the nodal functions by encouraging visitors to break their journey and extend the length of their visit through such marketing activities as providing more information about the nodes and offering special deals combining transport and accommodation would be challenging. International passengers appeared more likely than regional or other domestic travelers to respond to such strategies.

[Include Table 1 about here]

While analyzing demand is important in developing such strategies, it is also essential to examine and understand the issues from the supply-side as these stakeholders will be the ones involved in implementing any new measures and offering new services or products. To this end semi-structured in-depth interviews were undertaken with a range of suppliers to obtain their views on how tourism in Wellington and Picton might be developed by attracting transient Cook Strait passengers to visit and stay longer. In 2005, a total of twenty interviewees were chosen among those directly related to tourism and transport across the Cook Strait, notably those in Wellington and Picton. The sample included respondents from a range of tourism sectors such as accommodation providers in Wellington and Picton (three motels, one holiday park and three backpackers); the two ferry operators and other transport companies (e.g. one regional airline and two rental car companies), government and support organizations (one regional tourism organization, the Department of Conservation, visitor information centers in Wellington and Picton and one non-governmental organization); one tourism operator; and two attractions (a large one in Wellington and a small one in Picton). For the large companies and organizations usually the manager or the marketing manager was interviewed. For the small tourism operators the owner participated in the interviews. 
Lohmann, G. and D. G. Pearce (2012). "Tourism and transport relationships: the suppliers' perspective in gateway destinations in New Zealand." Asia Pacific Journal of Tourism Research 17(1): 14-29.

In contrast to passenger surveys which can provide answers to standardized questions regarding profiles and travel patterns (Graham \& Russell, 2001; Lohmann \& Pearce, 2010), semi-structured interviews with key providers were seen as a more effective way of identifying the issues important to them as it allowed the researchers to explore these in greater depth and follow up specific matters (Baird, 1999; Muir, et al., 2007). This flexibility was particularly important given the exploratory nature of the research. Issues covered included possible interactions and partnerships between transport and tourism companies and organizations to improve the destination functions of the gateway ferry ports as well as topical matters such as the impact of the fast ferry speed restrictions and the proposal to build another gateway ferry terminal in Clifford Bay. Content analysis was then undertaken on the transcripts from these interviews. This technique is based on examination of the data for recurrent instances that are systematically identified across the data set and grouped together by means of a coding system (Wilkinson, 2004). The next section highlights those findings.

\section{Findings}

Five major themes emerged from the analysis of the respondents' transcripts. The first two of these, place characteristics and products; and sales and marketing, relate to general features of tourism development and transport. The next two, cancellations; and speed restrictions and environmental impacts, reflect more specific transport issues and their impacts on tourism. The fifth, multiple gateways, illustrates issues that may arise when new gateways are developed and the effect this might have on existing nodal functions. These themes manifest themselves differently in Wellington and Picton and are generally more significant in the smaller of the two places.

\section{Place Characteristics and Products}

\section{Wellington}

Wellington has changed significantly in the last few years and has developed an image of a vibrant and cultural city. The interviewees were unanimous in affirming that the driving force behind the development of Wellington as a destination was the 
Lohmann, G. and D. G. Pearce (2012). "Tourism and transport relationships: the suppliers' perspective in gateway destinations in New Zealand." Asia Pacific Journal of Tourism Research 17(1): 14-29.

establishment of Te Papa. Together with Te Papa, many other events, attractions and facilities are sustaining the new image Wellington is promoting. However, some interviewees considered that the capital city still faced two major challenges: the lack of major attractions other than Te Papa and the lack of commissionable products for travel agents and tour operators due to many of the attractions being free (Pearce, Tan, \& Schott, 2004). The location of The Interislander ferry terminal outside the CBD was perceived as another factor that leads ferry passengers not to spend time in the city.

\section{Picton}

Apart from competing with the major national destinations (e.g. Auckland, Rotorua, Wellington, Christchurch and Queenstown), Picton was also seen to struggle with the destinations and attractions located in the Marlborough and Nelson regions, such as the vineyards in Blenheim, whale watching in Kaikoura, and tramping and kayaking in Abel Tasman National Park. In terms of the range of attractions that Picton provides, these are very much concentrated on outdoor and marine activities, which are particularly appealing during summer time. With the exception of the aquarium and the museum, which are both very small attractions, the remaining tourist activities in Picton are only suitable during fine weather. In the words of the manager from the Department of Conservation:

There are very few things to do in Picton if it is raining because Picton is so outdoor orientated, not everyone wants to walk in a muddied area [...] The other thing is that years ago Picton used to have its own picture theatre, had a lot of services that we don't see now because of the way people now travel straight through. Places that pick up the biggest slice of the pie in Picton are really the motel and the hotel owners and the food suppliers and the restaurants and petrol stations to a certain extent.

The interviewees proposed some new tourist attractions for Picton, including in-door family type activities, such as a fun park. This sort of attraction would probably fit well with the markets that Picton already has. The key argument was that: "there are a lot of families that come here because it is affordable for families and there is not enough for their kids to do. If you had an indoor attraction with water you would make a goldmine. I would love to do it" (Picton tour operator). This idea could appeal not only to gateway 
Lohmann, G. and D. G. Pearce (2012). "Tourism and transport relationships: the suppliers' perspective in gateway destinations in New Zealand." Asia Pacific Journal of Tourism Research 17(1): 14-29.

travelers, but also to the domestic market, especially the family type of tourists from the South Island that visit Picton during summer. Other suggestions included a bungee jump, movie theatre, a cable car or gondola and more events, particularly conventions and conferences. In many cases it seems that the interviewees were just trying to benchmark the success of other destinations in the country, rather than really proposing attractions that would fit with Picton's needs, themes and markets.

\section{Sales and Marketing}

Travellers going to or passing through Wellington and Picton require various services which provide a range of opportunities for promoting and selling transport and tourism products. Many tourism businesses earn extra revenue making reservations for The Interisland Line services. As the manager of a hostel in Wellington mentioned "a large part of our travel sales products is ferry tickets and it is a good income for us". On the other hand, the ferry companies also make bookings for their passengers for accommodation and rental cars on both sides of the Cook Strait, either through the packages they provide or at the information desk onboard the vessels.

In Wellington, the suppliers seem to have a good relationship with the ferry operators, particularly The Interisland Line. The manager of a large tourist attraction in the capital city said that the initiatives they have put forward in the past have been warmly received by the ferries. In Picton, on the other hand, some of the suppliers had reservations about The Interisland Line, the major complaint being that the company charged $10 \%$ commission when they booked their passengers into another product (e.g. accommodation or activities in Picton), but only paid 5\% when another business (e.g. an accommodation provider) booked ferry tickets for its clients. The Interisland Line reduced its agents' commission incentives on the basis that this would become a contribution rather than a commission.

The ferry companies, particularly The Interisland Line, have well-established distribution channels to sell tickets and make other products available such as packages combining a crossing with accommodation or attractions. However, the view of one ferry manager was that the packages are only just something extra that the ferry 
Lohmann, G. and D. G. Pearce (2012). "Tourism and transport relationships: the suppliers' perspective in gateway destinations in New Zealand." Asia Pacific Journal of Tourism Research 17(1): 14-29.

company provides. This was not the company's main role and that although they "provide a large number of people into that region [Marlborough]; it is over to the region to then decide how they best persuade those people to stay". In other words, while the ferry companies, particularly The Interisland Line, invest a significant amount of money promoting the region and its products he considered that the main job of the ferries is to transport people and that it is up to the region to develop its own strategies to capture this demand. In general the suppliers did not believe that the packages provided by the ferries were essential in terms of developing packages. As one hostel owner in Picton commented:

I don't necessarily see that they [The Interisland Line] have to provide a package, but they have to make it user friendly so there are transport links there. The information centres, the accommodation places, they can do packages as long as people have access to the ferry ticket at a reasonable price.

A lack of marketing resources to strengthen the destination function in both nodes was also noted, particularly in Picton. Over the past decade Wellington has had an active and successful marketing program led by its destination marketing organization, Positively Wellington Tourism, in association with the city's major hotels and other industry partners, including the ferry companies. Joint promotion, however, is not always easy. For example, according to Te Papa's Marketing Manager, when the museum was hosting the Lord of the Rings exhibition, which was a paid exhibition, The Interisland Line was "more than happy to have a poster displayed in the terminals" but... "there is a financial limit in terms of money [as] they need to earn money through advertisements onboard the ferries and we don't have the budget to afford that'.

Picton has significantly fewer resources to attract tourists than Wellington. With a smaller economy, fewer residents and a tourism sector comprised exclusively of small businesses, there are not many opportunities and funds to promote it. The suppliers consider that the marketing and promotion are usually less than ideal. Apart from the shortage of resources, owners and managers also lack the time and ability to explore further possibilities existing in the region. With the exception of the wineries in the Marlborough region that have sufficient funds to market themselves, most of the 
Lohmann, G. and D. G. Pearce (2012). "Tourism and transport relationships: the suppliers' perspective in gateway destinations in New Zealand." Asia Pacific Journal of Tourism Research 17(1): 14-29.

marketing initiatives rely on Destination Marlborough and the transport providers, i.e. the ferry companies, notably The Interisland Line, and SoundsAir. The wineries are perceived to dominate the promotion done by these other organisations and wine tourism is not seen to help much in terms of the other ' $\mathrm{W}$ ' products (water and wild) that Picton offers.

\section{Ferry Cancellations}

Cancellation of the ferry services is usually due to weather conditions that may disrupt Cook Strait sailings. This is one of the main reasons that make passengers change their length of stay either in Wellington or in Picton (Lohmann, 2009). Due to its size and how the accommodation sector is structured in Picton, the impact of ferry cancellations is usually higher there than in Wellington. None of the Wellington interviewees located perceived cancellations as a major issue. It seems that the capital city is able to readily accommodate the needs of hundreds of extra travelers.

Three sets of views emerged from the Picton respondents. Firstly, cancellations, which sometimes last for a day or two, are good for Picton as they make travelers stay in the town until the ferry operations resume. Due to the size of the vessels, these circumstances can create a need for accommodation, activities and catering for hundreds of passengers, which is usually enough to make most tourism providers fully booked. While some people get frustrated because their holiday is delayed, others take the opportunity to look around Picton and engage in activities. A second group thought that while the ferry cancellations make passengers waiting in Picton stay longer in the town most businesses also end up losing bookings from passengers who are coming from Wellington. As passengers in Wellington also cannot cross the Cook Strait in these circumstances, once the services resume they usually prefer to move on, in order to keep up with their itineraries, rather than to stay in Picton. Finally, there are those businesses that only lose when services are cancelled. Apart from the ferry operators, rental car companies also face challenging situations, as the manager of a rental car company in Picton explains: 
Lohmann, G. and D. G. Pearce (2012). "Tourism and transport relationships: the suppliers' perspective in gateway destinations in New Zealand." Asia Pacific Journal of Tourism Research 17(1): 14-29.

It is a nightmare, really. It is a bit chaotic. We rely on fleet management, logistics for us is essential. For a start we will have people that arrived from the ferries turning up to pick their car. But then clients who already have a car and are not able to catch the ferry because it has been cancelled they may ask: 'can I keep my car for an extra day?' And we never turn down an extension. Then people start doing strange things like flying to Christchurch or Wellington because they don't want to wait. If someone says a ferry was cancelled and they are going to Picton and we are expecting them to turn up, but they couldn't turn up because the ferry was cancelled, we wouldn't charge that person for the rental. Generally we don't charge for people that don't turn up, no-show.

While it seems that some interviewees consider the cancellation as an opportunity to have the town packed with visitors and their businesses running at full capacity, it is clear that the experience of being forced to stay in any destination is not the best. In addition, even though some passengers will take advantage of the cancellation to visit and enjoy Picton, this experience will not be the best as not only are the conditions for visiting Picton not ideal due to the bad weather but places and attractions will also be crowded.

\section{Speed Restrictions and Environmental Impacts}

After the introduction of the fast ferries in the Cook Strait market in 1994 and during several periods after that, the community of Picton and the Marlborough Sounds was concerned about the environmental impacts caused by the wash of these vessels. This episode created a strained relationship between the fast ferry operator, The Interisland Line, and the community in Picton, who set up an organization called Save the Sounds Stop the Wash. The introduction of fast ferry technology created a market for day trips and short breaks across Cook Strait, especially favored by those living in Wellington. Visitors could leave the city in the morning and arrive back in the evening. The wineries in Marlborough and the tour operators in Picton particularly benefited from day-trippers and the convenience of a fast ferry travelling at 35 knots. With the advent of speed restrictions in Tory Channel, however, and a proliferation of cheap airfares,

Wellingtonians opted to fly directly to Blenheim, the heart of the wine country. Tourism businesses in Picton, especially wine tour operators, ended up losing this niche market. Despite this loss, all the respondents interviewed in Picton supported the decision to 
Lohmann, G. and D. G. Pearce (2012). "Tourism and transport relationships: the suppliers' perspective in gateway destinations in New Zealand." Asia Pacific Journal of Tourism Research 17(1): 14-29.

reduce the ferries' speed, as it is important to protect the environment and beauty of the Marlborough Sounds.

\section{Threats and Opportunities of Multiple Gateways}

Another issue which emerged during the course of the interviews added a further dimension to the relationship between tourism and transport and gateway and destination functions - the proposal for another ferry terminal at Clifford Bay (see Figure 1). From a transport point of view, the main advantage of this project would be a more direct and faster ferry link between the North and South Islands. The route proposed would operate in open sea with no speed restriction imposed, although more cancellations might be expected, as Cook Strait can be quite rough sometimes, especially outside the sheltered waters of Tory Channel. On the other hand, losing the exclusiveness as the gateway ferry to the South Island could have significant impacts on Picton as part of the passing through traffic would be diverted to Clifford Bay.

Although the possibility of the ferries operating between Wellington and Clifford Bay now appears to have faded, it was a lively topic at the time the interviews were conducted (2005). No other topic made the interviewees talk more passionately than this one. Several reasons contribute to this reaction, but the paramount one is the question of Picton's survival without the ferries. On this matter, the respondents' opinions were quite diverse, with some managers and owners believing that Picton would struggle to maintain its economy, while others thought that not having the ferries would be the real opportunity for Picton to grow as a destination. Some interviewees considered that The Interisland Line used the Clifford Bay proposal to threaten Picton and the Marlborough Regional Council in order to obtain whatever they wanted. According to them, this situation happened during the debate about the fast ferries' speed restriction, with the ferry operator mentioning that Clifford Bay was a viable option to consider if a speed restriction was imposed. This ended up damaging the relationship between some tourism businesses operators in Picton and The Interisland Line.

Some respondents considered that losing the exclusiveness of the ferry gateway to the South Island would have significant ramifications for Picton. A number of businesses 
Lohmann, G. and D. G. Pearce (2012). "Tourism and transport relationships: the suppliers' perspective in gateway destinations in New Zealand." Asia Pacific Journal of Tourism Research 17(1): 14-29.

might never recover, such as restaurants, cafes and roadside motels on the way out of Picton. One accommodation manager said his business "would never be as good again. Its income would be cut in half, or quarter. The overall takings would be like winter takings all year round, which is really low. It wouldn't be worth being here". Probably the only time of the year when the absence of the ferries would not be felt would be during summer but very few businesses would be able to survive on summer income alone. The general opinion was that not only Picton would suffer but so would Blenheim and the whole Marlborough region. With the move to Clifford Bay, there would be no need for the trains to go to Blenheim and Picton and few passengers would drive back to visit these two destinations. Other places on the route between Clifford Bay and Christchurch would benefit from it, especially Kaikoura and Hanmer Springs.

For some others the Clifford Bay proposal was a wake-up call for the whole town. One of the board members of the Picton-based promotional organization called Picton Sounds Paradise (PSP) stated that:

Motels, particularly, never belonged to anything, they never contributed to anything. Now they think: I have an investment here, I have to protect it. I have to create a market for myself and I have to think about my business.

This suggests some businesses have just been relying on the ferries in order to bring in clients but never tried to develop new markets so they could be less dependent on ferry passengers. The Clifford Bay threat forced them to promote themselves and to develop Picton. Several interviewees held the view that the town could benefit if the ferries moved away from Picton. They believed Picton would be able to develop itself as a true tourist destination without the ferry infrastructure and its gateway function. Supporters of this argument say the absence of a ferry terminal would make the Marlborough Sounds the focus for people visiting Picton. A backpacker owner summed up the situation thus:

If it did go ahead [the Clifford Bay proposal], I would now be more confident of Picton's development as a tourist destination than I used to be. Simply because: a) we have a convenient ferry line that is going to last [Bluebridge] and b) Picton and the Sounds have developed their own identity - the Queen Charlotte track, the Sounds and its waterways, and 
Lohmann, G. and D. G. Pearce (2012). "Tourism and transport relationships: the suppliers' perspective in gateway destinations in New Zealand." Asia Pacific Journal of Tourism Research 17(1): 14-29.

accommodation properties have all created a demand. [...] People usually like Picton. So, a momentum has started, which will continue.

However, Picton would need to market itself and also develop attractions and activities to sustain the tourism industry outside the summer season.

The Clifford Bay proposal was less of an issue amongst the Wellington respondents. In the view of a manager of a tourist attraction in Wellington, the capital city could also benefit from a move of the ferries to Clifford Bay. His argument was that the shorter trip across the Cook Strait could make people leave later or arrive earlier in the capital city.

\section{Discussion and Conclusions}

This analysis of supplier perspectives in two places linked by ferry services has revealed a range of ways in which tourism development and transport are closely intertwined and shown how the nature and importance of these links might vary depending on the character and nodal functions of each place. The issues which arose relating to product development, sales and marketing, cancellations, the introduction of fast ferries and the new port proposal were generally much more significant in Picton than in Wellington. This might be attributed to the marked size difference between the two, the relatively more significant gateway function of the smaller port (Table 1) and its greater dependence on the ferry traffic. In terms of promotion, for example, Picton lacks the scale and resources to promote itself more aggressively, the number and size of the local businesses there stand in marked contrast to the size and influence of the most dominant player, The Interisland Line; and the cancellation of sailings has a major short-term impact on the town. While the ferry services are also important to Wellington they do not have the same dominance there - the city's airport is the country's busiest domestic air hub and also has international air connections; the chain hotels in the capital are much larger than the accommodation businesses in Picton; and in Te Papa there is a major attraction.

The study also suggests that in these two cases, and particularly that of Picton, the task of capturing a greater share of transiting ferry passengers, increasing their length of stay 
Lohmann, G. and D. G. Pearce (2012). "Tourism and transport relationships: the suppliers' perspective in gateway destinations in New Zealand." Asia Pacific Journal of Tourism Research 17(1): 14-29.

and thereby converting more of the gateway and stopover functions of the nodes is challenging and not as easy as it might first appear. Picton especially currently lacks the product and the resources to significantly increase promotion of the town and challenges also appear in developing attractive packages combining ferry travel with accommodation and/or attractions to encourage longer visits. With its larger size and wider range of attractions the gateway function of Wellington is already relatively less important there and engagement with the local tourism industry is much greater. The supply-side findings reinforce and complement the results of the demand study that indicated there was limited potential to alter the travel behavior of ferry passengers passing through the two centers (Lohmann \& Pearce, 2010). In this respect the experience of Wellington and Picton as gateways for ferry traffic contrasts markedly with that of the large intercontinental air transport hubs such as Dubai, Hong Kong and Singapore which appear to have been much more successful in capturing a share of the traffic passing through their airports. The latter, however, has come about through large scale infrastructure investment, wide-ranging and supportive government policies, extensive promotion and strategic access to major flows of international air travelers (Chang \& Raguraman, 2001; Lohmann, et al., 2009; Low \& Heng, 1997). As these conditions do not prevail in the study areas the prospects for ferry transport to further contribute to the growth in tourism there should therefore not be over-stated.

Another issue that emerged during this study is the notion that multi-nodal functions may not only change over time but also have a cyclical or seasonal dimension as well; that is, gateway or destination functions may change throughout the year. Due to its scale and geographical characteristics, Picton is more sensitive to the seasonal disparity in visitor numbers, with its outdoor and marine activities being more appealing during the warmer weather. In summer the town grows from 4,000 people to about 20,000, especially with visitors attracted by holiday homes and the marina, the biggest in the South Island. Summer is the time of the year when businesses rely not only on ferry passengers but also on other travelers, predominantly from the South Island. The foreshore and holiday homes in particular attract a lot of families. From January to March the length of stay is longer than during the rest of the year when the common pattern is for guests to stay only one night, a characteristic of the gateway/stopover 
Lohmann, G. and D. G. Pearce (2012). "Tourism and transport relationships: the suppliers' perspective in gateway destinations in New Zealand." Asia Pacific Journal of Tourism Research 17(1): 14-29.

function. Indeed, the owner of a motel commented that "Picton becomes more of a destination at that time of the year". Winter, on the other hand, is the season when the town relies particularly on gateway travelers from the ferries. More attention might therefore be directed at studying changing multi-nodal functions on a seasonal basis as well as over longer periods and the role transport plays in this.

More generally, this study has raised a series of broader research issues regarding the relationships between transport and tourism development that merit closer attention. Firstly, the differences which have emerged between Wellington and Picton have underlined the importance of place in such research, a point that also emerged in the case of Hobart (Muir, et al., 2007). While models such as those by Prideaux (2000) and Dredge (1999) are useful in terms of drawing attention to key features of development or place functions, the characteristics of places and their relative position in visitor circuits will play a significant role in the way in which and extent to which transport and tourism development are inter-linked. More empirical research is needed in different contexts to further elucidate the impact of place. Given that ferry and other services link at least two nodes, research involving a comparative element such as that used here may be especially fruitful in this regard. The discussion of the likely impact of the Clifford Bay proposal suggests extending analyses to include other, perhaps competitive, nodes could provide further insights into multi-functional nodes and how these evolve over time through the interplay of developments in tourism and transport. Particularly when the emphasis is on development and changing nodal functions, longitudinal research that focuses on changing transport conditions has a key role to play, though tracking change and determining causal links over time has its challenges (Lawless \& Gore, 1999; Pearce, 2001a; Tremblay \& Gariépy, 1995). Other research might investigate the differing impacts which different modes of transport have on the functions exercised by a single node, for example, what are the respective roles of ferry, airline, cruise, rail and road services in Wellington.

The issues raised by the respondents in this study also suggest considerable scope exists to extend research on transport and tourism beyond the current emphasis on such themes as changing access and the carriage of passengers to other aspects, especially 
Lohmann, G. and D. G. Pearce (2012). "Tourism and transport relationships: the suppliers' perspective in gateway destinations in New Zealand." Asia Pacific Journal of Tourism Research 17(1): 14-29.

sales and marketing. As this study has demonstrated, the way in and extent to which local tourism businesses cooperate with each other and engage with carriers to promote a destination can have a significant impact on its development. The role of airlines in this regard is well recognized, but relatively little work has yet been done on surface transport where research on basic questions relating to distribution is still relatively sparse (Pearce \& Sahli, 2007) and issues relating to joint marketing and bundling products to develop particular places is largely unexplored. A central issue here is investigation of the power relationships and dynamics between the carrier as a dominant player and the multitude of smaller businesses, which commonly characterize the accommodation and attractions sectors (Buhalis, 2000).

In pursuing research on these and other topics examining the links between transport and tourism development this study has shown the value of including a supply-side perspective. To understand these issues more fully, research in this field needs to go beyond passenger surveys, narrowly focused modal studies and policy analysis and give greater voice to tourism suppliers in order to examine their views and interactions with the transport sector.

\section{Acknowledgements}

This research was made possible through a CAPES Foundation scholarship (Brazilian Ministry of Education) received by Dr Gui Lohmann in order to undertake his $\mathrm{PhD}$ at Victoria University of Wellington.

\section{List of References}

Baird, A. (1999). A Comparative Study of the Ferry Industry in Japan and the UK. Transport Reviews, 19(1), 33-55.

Bowden, J. (2006). A Logistic Regression Analysis of the Cross-Cultural Differences of the Main Destination Choices of International Tourists in China's Main Gateway Cities. Tourism Geographies, 8(4), 403 - 428. 
Lohmann, G. and D. G. Pearce (2012). "Tourism and transport relationships: the suppliers' perspective in gateway destinations in New Zealand." Asia Pacific Journal of Tourism Research 17(1): 14-29.

Buhalis, D. (2000). Relationships in the Distribution Channel of Tourism: Conflicts between Hoteliers and Tour Operators in the Mediterranean Region. International Journal of Hospitality \& Tourism Administration, 1(1), 113-139.

Burghardt, A. F. (1971). A Hypothesis About Gateway Cities. Annals of the Association of American Geographers, 61(2), 269-285.

Butler, R. W. (1980). The Concept of the Tourist Area Cycle of Evolution: Implications for Management of Resources. Canadian Geographer, 24(1), 5-12.

Caruana, V., \& Simmons, C. (1995). The Role of Traffic Growth and Capital Investment from 1918-82 in the Development of Manchester Airport as an International Gateway. Journal of Transport Geography, 3(3), 199-219.

Caves, R. E., \& Gosling, G. D. (1999). Strategic Airport Planning. Oxford: Pergamon.

Chang, T. C., \& Raguraman, K. (2001). Singapore Tourism: Capital Dimensions and Regional Connections. In P. Teo, T. C. Chang \& K. C. Ho (Eds.), Interconnected Worlds: Tourism in Southeast Asia (pp. 47-63). Oxford: Pergamon.

Dennis, N. (1994). Airline Hub Operations in Europe. Journal of Transport Geography, 2(4), 219-233.

Doorne, S. M. (2000). Tourism the Capital City. In J. McConchie, D. Winchester \& R. Willis (Eds.), Dynamic Wellington: A Contemporary Synthesis and Explanation of Wellington (pp. 217-232). Wellington: Victoria University of Wellington.

Dredge, D. (1999). Destination Place Planning and Design. Annals of Tourism Research, 26(4), 772-791.

Duval, D. T. (2007). Tourism and Transport: Modes, Networks and Flows. Clevedon: Channel View Publications.

Ewert, A. W. (1996). Gateways to Adventure Tourism: The Economic Impacts of Mountaineering on One Portal Community. Tourism Analysis, 1(1), 59-63.

Fleming, D. K., \& Hayuth, Y. (1994). Spatial Characteristics of Transportation Hubs: Centrality and Intermediacy. Journal of Transport Geography, 2(1), 3-18.

Framke, W. (2002). The Destination as a Concept: A Discussion of the Business-Related Perspective Versus the Socio-Cultural Approach in Tourism Theory. Scandinavian Journal of Hospitality and Tourism, 2(2), 92-108.

Graham, A., \& Dennis, N. (2010). The Impact of Low Cost Airline Operations to Malta. Journal of Air Transport Management, 16(3), 127-136.

Graham, M., \& Russell, V. (2001). Inverclyde Ferry Services: A Passenger Segmentation Analysis. Journal of Vacation Marketing, 7(3), 221-233.

Khadaroo, J., \& Seetanah, B. (2007). Transport Infrastructure and Tourism Development. Annals of Tourism Research, 34(4), 1021-1032.

Lawless, P., \& Gore, T. (1999). Urban Regeneration and Transport Investment: A Case Study of Sheffield 1992-96. Urban Studies, 36(3), 527-545.

Lew, A., \& McKercher, B. (2002). Trip Destinations, Gateways and Itineraries: The Example of Hong Kong. Tourism Management, 23(6), 609-621.

Ley, D., \& Murphy, P. (2001). Immigration in Gateways Cities: Sydney and Vancouver in Comparative Perspective. Progress in Planning, 55(3), 119-194.

Lohmann, G. (2009). Transport and Tourism: Developing Gateways as Tourist Destinations. Cologne: LAP LAMBERT Academic Publishing.

Lohmann, G., Albers, S., Koch, B., \& Pavlovich, K. (2009). From Hub to Tourist Destination - an Explorative Study of Singapore and Dubai's Aviation-Based Transformation. Journal of Air Transport Management, 15(5), 205-211.

Lohmann, G., \& Pearce, D. G. (2010). Conceptualizing and Operationalizing Nodal Tourism Functions. Journal of Transport Geography, 18(2), 266-275.

Low, L., \& Heng, T. M. (1997). Singapore: Development of Gateway Tourism. In F. M. Go \& C. L. Jenkins (Eds.), Tourism and Economic Development in Asia and Australasia (pp. 237-254). London: Cassell.

Miossec, J. M. (1977). Un Modèle de l'Espace Touristique. L'Espace Géographique 6(1), 41-48.

Mistilis, N., \& Dwyer, L. (1999). Tourism Gateways and Regional Economies: The Distributional Impacts of MICE. International Journal of Tourism Research, 1(6), 441-457.

Muir, S., Jabour, J., \& Carlsen, J. (2007). Antarctic Gateway Ports: Opening Tourism to Macquarie Island and the East Antarctic from Hobart. Tourism in Marine Environments, 4(2-3), 135-150. 
Lohmann, G. and D. G. Pearce (2012). "Tourism and transport relationships: the suppliers' perspective in gateway destinations in New Zealand." Asia Pacific Journal of Tourism Research 17(1): 14-29.

Mules, T. (2005). Economic Impacts of National Park Tourism on Gateway Communities: The Case of Kosciuszko National Park. Tourism Economics, 11(2), 247-259.

Murphy, P. E., \& Keller, C. P. (1990). Destination Travel Patterns: An Examination and Modeling of Tourist Patterns on Vancouver Island, British Columbia. Leisure Sciences, 12(1), 49-65.

O'Connor, K. (1995). Airport Development in Southeast Asia. Journal of Transport Geography, 3(4), 269-279.

Page, S. (1994). Transport for Tourism. London; New York: Routledge.

Page, S. (2001). Gateways, Hubs and Transport Interconnections in Southeast Asia: Implications for Tourism Development in the Twenty-First Century. In P. Teo, T. C. Chang \& K. C. Ho (Eds.), Interconnected Worlds: Tourism in Southeast Asia (pp. 84-99). Oxford: Pergamon.

Pearce, D. G. (1987). Mediterranean Charters: A Comparative Geographic Perspective. Tourism Management, 8(4), 291-305.

Pearce, D. G. (1989). Tourist Development (2 ed.). Harlow \& New York: Wiley.

Pearce, D. G. (2001a). Tourism and Urban Land Use Change: Assessing the Impact of Christchurch's Tourist Tramway. Tourism and Hospitality Research, 3(2), 132-148.

Pearce, D. G. (2001b). Towards a Regional Analysis of Tourism in Southeast Asia. In P. Teo, T. C. Chang \& K. C. Ho (Eds.), Interconnected Worlds: Tourism in Southeast Asia (pp. 27-43). Oxford: Pergamon.

Pearce, D. G. (2007). Capital City Tourism: Perspectives from Wellington. Journal of Travel and Tourism Marketing, 22(3/4), 7-20.

Pearce, D. G., \& Sahli, M. (2007). Surface Transport Distribution Channels in New Zealand: A Comparative Analysis. Journal of Travel and Tourism Marketing, 22(2), 73-87.

Pearce, D. G., \& Tan, R. (2004). Distribution Channels for Heritage and Cultural Tourism in New Zealand. Asia Pacific Journal of Tourism Research, 9(3), 225-237.

Pearce, D. G., Tan, R., \& Schott, C. (2004). Tourism Distribution Channels in Wellington, New Zealand. International Journal of Tourism Research, 6, 397-410.

Prideaux, B. (2000). The Resort Development Spectrum -- a New Approach to Modeling Resort Development. Tourism Management, 21(3), 225-240.

Short, J. R., Breitbach, C., Buckmand, S., \& Essex, J. (2000). From World Cities to Gateway Cities: Extending the Boundaries of Globalization Theory. City, 4(3), 317-340.

Tremblay, F., \& Gariépy, M. (1995). Anticipation Et Prise En Compte Des Impacts Cumulatifs. A Propos Du Développement Touristique En Milieu Urbain. Cahiers du Géographie du Québec, 39(107), 255-273.

Wilkinson, S. (2004). Focus Group Research. In D. Silverman (Ed.), Qualitative Research Theory, Methods and Practice (2 ed., pp. 177-199). London: Sage.

Yin, K. R. (2003). Case Study Research, Design and Methods (3rd ed.). London: Sage.

Yuan, M. S., \& Christensen, N. A. (1994). Wildland-Influenced Economic Impacts of Nonresident Travel on Portal Communities: The Case of Missoula, Montana. Journal of Travel Research, 32(4), 2631.

Zurick, D. N. (1992). Adventure Travel and Sustainable Tourism in the Peripheral Economy of Nepal. Annals of the Association of American Geographers, 82(4), 608-628. 
Lohmann, G. and D. G. Pearce (2012). "Tourism and transport relationships: the suppliers' perspective in gateway destinations in New Zealand." Asia Pacific Journal of Tourism Research 17(1): 14-29.

Table 1 Nodal functions of Wellington and Picton for ferry passengers (Source: Lohmann \& Pearce, 2010).

\begin{tabular}{|r|r|r|r|r|r|r|}
\hline & \multicolumn{1}{|c|}{ Origin } & \multicolumn{1}{|c|}{$\begin{array}{c}\text { Gateway } \\
\text { Traveler }\end{array}$} & $\begin{array}{c}\text { Overnight } \\
\text { Gateway } \\
\text { Visitor }\end{array}$ & $\begin{array}{c}\text { Stopover } \\
\text { Visitor }\end{array}$ & $\begin{array}{c}\text { Destination } \\
\text { Tourist }\end{array}$ & Total \\
\hline Wellington & $17.4 \%$ & $26.8 \%$ & $11.3 \%$ & $20.3 \%$ & $24.1 \%$ & $100.0 \%$ \\
\hline Picton & $0.8 \%$ & $67.0 \%$ & $11.4 \%$ & $13.0 \%$ & $7.8 \%$ & $100.0 \%$ \\
\hline
\end{tabular}


Lohmann, G. and D. G. Pearce (2012). "Tourism and transport relationships: the suppliers' perspective in gateway destinations in New Zealand." Asia Pacific Journal of Tourism Research 17(1): 14-29.

Figure 1 Major tourist destinations in New Zealand and the Cook Strait ferry actual and proposed routes.
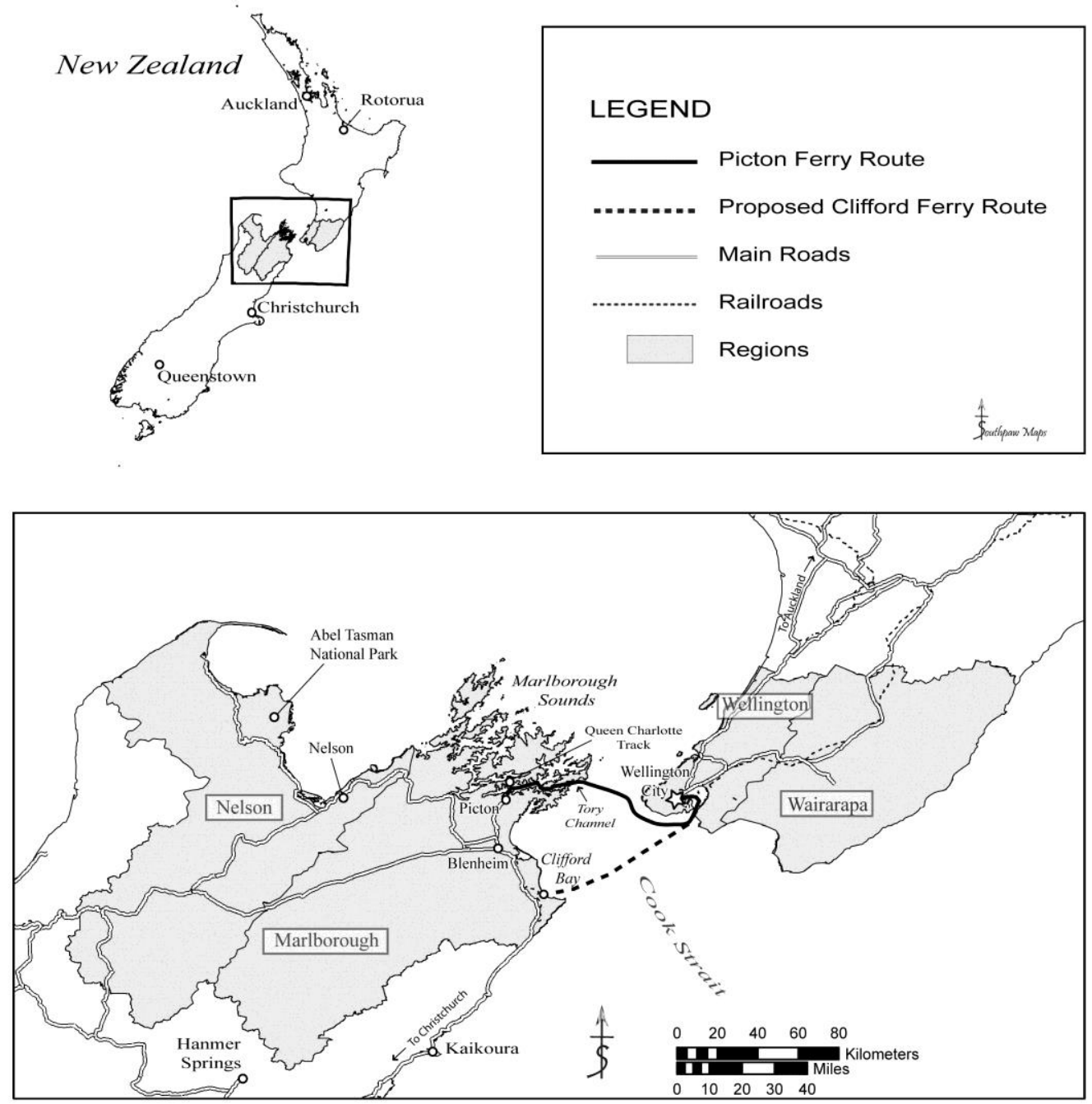